\title{
Facing emergences: Past traces and new directions in American anthropology (Why American anthropology needs semiotics of culture)
}

\author{
Irene Portis-Winner \\ 986 Memorial Dr, Apt 404 \\ Cambridge MA 02138, USA \\ e-mail: tgipwinner@comcast.net
}

\begin{abstract}
This article considers what happened to American anthropology, which was initiated by the scientist Franz Boas, who commanded all fields of anthropology, physical, biological, and cultural. Boas was a brave field worker who explored Eskimo land, and inspired two famous students, Ruth Benedict and Margaret Mead, to cross borders in new kinds of studies. After this florescence, there was a general return to linear descriptive positivism, superficial comparisons of quantitative cultural traits, and false evolutionary schemes, which did not introduce us to the personalities and inner worlds of the tribal peoples studied. The 1953 study by the philosopher David Bidney was a revelation. Bidney enunciated and clarified all my doubts about the paths of anthropology and his work became to some extent a model for a narration of the story of American anthropology. In many ways he envisaged a semiotics of culture formulated by Lotman. I try to illustrate the fallacies listed by Bidney and how they have been partially overcome in some later anthropological studies which have focused on symbolism, artistry, and subjective qualities of the people studied. I then try to give an overview of the school started by Lotman that spans all human behavior, that demonstrates the complexity of meaning and communication, in vast areas of knowledge, from art, literature, science, and philosophy, that abjured strict relativism and closed systems and has become an inspiration for those who want anthropology to encompass the self and the other, and Bahtin's double meaning. This paper was inspired by Bidney as a call to explore widely all possible worlds, not to abandon science and reality but to explore deeper inner interrelations and how the aesthetic may be indeed be paramount in the complexities of communication.
\end{abstract}




\section{Part 1}

\subsection{Introduction: Bidney's Theoretical Anthropology}

How did I begin this essay? The subtitle of the March 2005 issue of the American Anthropologist (107/1) was Ethnographic Emergences. This sparked a memory of a book that fascinated me years ago by the philosopher David Bidney, entitled Theoretical Anthropology (1967, first published in 1953). Bidney's core word was “emergences". I was then inspired to reflect on some of Bidney's far-sighted critiques and arguments, many of which foreshadowed the perspectives of the growing semiotic movements.

Why had I never heard that phrase "emergences" in the remarks of the professors at Columbia where I was a student, and the university that, thanks to Franz Boas, had founded the first department of anthropology? While Boas was a brilliant and inventive master of all aspects of anthropology, his work was soon ignored with some exceptions until recently. Bidney's evaluations were also ignored by anthropologists with the exception of Kroeber. Indeed, after the virtual fluorescence of creativity by two of Boas' students: Margaret Mead, who had the courage to embark on fieldwork alone at the age of twenty-five in Oceania, who had the gift of empathy and creativity to perceive and translate the gestures and beliefs of three different groups, and the second student, Ruth Benedict, who was indeed a philosopher and poet as well as an anthropologist. She saw as a metaphor a Neitchian tint in the worldview of the plains Indians and she poetically depicted the Zuni as Apollonian. Such contributions enrich our minds whether or not they are epistemologically real, in Searle's terminology.

But the work of these two gifted individuals originally celebrated, nevertheless with some exceptions, were neglected for decades for tired methodologies, positivist and descriptive and static portraits which omitted the history of the various tribal groups, which were distilled in isolation as in a museum and were depicted as retaining their cultures as frozen, and incorrect evolutionary schemes presumed to be universal. 
Boas' great contributions were hardly examined by the growing new field of anthropologists, although Boas liberated cultural theory from the strict, unsubstantiated linear evolutionary rules proposed by Morgan and Spencer. Boas was incorrectly called anti-historical, although he upheld the importance of historical evidence of primitive peoples, in so far as it could be substantiated from myths, memories, and some artifacts. Indeed, while Darwin collected quantities of empirical data to support his emerging theory of diversity in evolution, nevertheless the myth of unilineal evolution continued to be taken seriously by many. Thus the early heritage was distorted with few exceptions. Boas courageously broke down myths and stereotypes concerning racial and ethnic traits and false evolutionary beliefs, and showed for example, that any language could be learned by any infant, thus there was no universal evolutionary path for language development.

Bidney's oeuvre had been silenced, with some exceptions such as the writings of Kroeber. In this paper, I review some of Bidney's ideas and then consider American anthropological writings exemplifying the very fallacies he discusses and others that embrace some of Bidney's far-seeing insights. But few examples exhibit the breadth and brilliance of Peirce's vision, nor that of Lotman's semiotics of culture and the work of his colleagues, as well as that of Roman Jakobson, all of which were not available to Bidney.

\subsection{Reflections on David Bidney's insights into a semiotics of culture}

Bidney (1967: 37) held that he offered a "first statement, so far as I know, of the doctrine of emergent evolution, as applied to the history of human civilization".

As Bidney (1967: 40) reminds us, according to Aristotle, the sciences were arranged in a hierarchical order according to their degree of abstraction, a view challenged by Descartes, Bacon, Voltaire, as well as Bidney, all of whom questioned the idea of continuity and plenitude. 
Foreseeing, sharing and critiquing Darwinian thoughts, they believed that some species were now extinct and others were in the process of extinction. Referring to the ideas of critical rationalists, Bidney (1967: 43) asserted that the Darwinian "sceptics indicated that there do seem to be leaps in nature and the assumption of a continuous scale of being is nothing but a product of 'presumptuous imagination"”.

As Bidney noted, John Locke "denied that man has any knowledge of 'real essences', and concluded that our conception of species are only 'nominal essences', which do not correspond to any fixed natural boundaries in natural species" (Bidney 1967: 44; quoting Locke 1979 [1824]). For Bidney, evolution is possible because there is continuity in the development of living beings, but also there is emergence of novelties or qualitative variation (Bidney 1967: 47). Aristotle's principle of "the hierarchical continuum" was combined with the evolutionary principle of the transformation of species (Bidney 1967: 47).

Bidney's close collaborator, Alfred Kroeber, the leading anthropologist following Boas, who established a second department of anthropology at the University of California, was indeed a historian who brought to the fore empirically established historical facts, but he upheld the complete separation of the organic and the superorganic. In 1945, this was partially rejected by Kroeber himself in his dynamic concept of change which liberated the diversity and freedom of the critical mind of the individual, which was the position of Boas. Referring to his friend Kroeber, Bidney wrote that although originally he "mistakenly saw strict separation of organic and social, I nevertheless called for the special qualities in the development cultural phenomenon" (Bidney 1967: 37). Bidney quotes Kroeber:

A new factor has arisen $[\ldots]$ a factor that had passed beyond natural selection, that $[\ldots]$ rocked and swayed by the oscillations of heredity that underlay it, nevertheless floated unimmersibly upon it [...] The dawn of the social that is not a link in any chain, not a step in a path, but a leap to another plane. (Bidney 1967: 37) 


\section{8}

Bidney writes that as far as he knows, these words are "the first statement of the doctrine of emergent evolution as applied to the history of human civilization" (Bidney 1967: 37).

Referring to the causes of culture, Bidney held that only individual societies are the efficient cause of cultural processes, which must not be confused with the formal and material conditions and cultural activities of persons in society (Bidney 1967: 33). Culture considered in its realistic and idealistic aspects requires a union of all forms of causality, rather than a focus on only unitary causal explanations such as the historical or Marxist ones, all of which ignore that man is a selfdetermining agent (Bidney 1967: 33).

Though not knowing Peirce, whose writings were hardly available, Bidney (Bidney 1967: 3) pointed out that "Man is a self-reflecting animal in that he alone has the ability to objectify himself, to stand apart from himself [...] Man alone is capable of reflection, of selfconsciousness, of thinking of himselves as an object". Humans are rational in the sense that they can conceive concepts or meanings as having universal significance. It is this ability to formulate concepts or symbols which renders man a symbolic animal and enables us to engage our logical, rational processes of thought. Non-human animals have the ability to perceive signs that have an immediate pragmatic value with reference to a given situation, but not referring to the past and the future. Nor can non-humans conceive of universal symbols or meanings and thereby create a language by which to communicate a cumulative result of their experience and reflections (Bidney 1967: 3). Thus, Peirce's far-sighted concept of "man as a sign" was suggested by Bidney as well as the possibility of animals' use of signs, which erodes the boundary between humans and non-humans, as well as the boundary between primitive man and man in civilization.

Bidney reflected that language originated from the human desire to communicate experiences and thoughts to others and that human speech is both a cause and effect of social communication, but human communication is the primary function of language (Bidney 1967: 4), which suggests Bahtin's dialogue and Jakobson's belief that dialogue precedes monologue. 
Bidney described the world of primitive man as an imaginary super sensuous world, a magic world of perpetual miracles where anything can happen and practically nothing is impossible. The primitive imagination is the source of poetry, religion, myth and art, and as Lévi-Strauss showed, also primitive science existed based on available context, and inventing bricolage. Later Eric Wolf revived the importance of imagination as the dominant source for ideology. "As a rational animal," Bidney wrote,

man is motivated by the quest for intelligibility, for meaning in his life and the world in which he exists. Because of his capacity for reflection and symbolic conceptualization man also seeks to understand the significance of his conduct, as well as his origins and destiny. Even primitive man $[\ldots]$ speculating upon the origin of his society and culture and attempts to provide some answer to the great enigmas of birth and death (Bidney 1967: 5).

Bidney concluded that "myth, religion, art, philosophy, and science are the historic expressions of man's quest for an intelligible world, for a world of meaning and value" (Bidney 1967: 5).

For Bidney, the dual nature of man is conveyed by his determinate psychobiological structure and function "and his indeterminate, historically acquired cultural personality [that] presupposes a certain measure of human freedom or self-determination" (Bidney 1967: 9). Such a position, taken by Bidney, was opposed to the deterministic, reification, or reductionist systems he viewed as fallacies.

\section{Part 2. Bidney's fallacies: Examples}

The following remarks discuss Bidney's fallacies, the use of which I believe has held back the development of American anthropology theory. 


\subsection{The positivist fallacy}

According to Bidney "The ultimate reality can be investigated by science but can never be completely known or verified as scientific theory and is subject to constant critical revisions" (Bidney 1967: 21). Practice refers to actual behavior, belief, and theory. Bidney holds that "the realists tend to confuse the actual aspects of culture with ideal culture by assuming that the covert or professed ideals are carried out in practice, whereas often this is not the case" (Bidney 1967: 32). This he calls the "positivistic fallacy" (ibid.).

\subsection{The normative fallacy}

According to Bidney (1967: 32), the normative idealists tend to define culture in terms of social ideals and tend to exclude the actual practice as not properly constitutive of culture, which may be called the "normativistic fallacy" or reification.

Bidney warns that it is not sufficient simply to describe a culture's practices, nor is it sufficient to assume that the ideals professed by the members of society are actually adhered to in practice. Every culture has its ideal and practical aspects and the social-scientist has to show the interrelation between the two areas.

\subsection{The metacultural fallacy}

Metaphysical fallacies of misplaced concreteness are the result of not viewing culture in both its theoretical and practical aspects. This would eliminate the necessity of trying to explain how it is possible for an abstract, logical structure to interact with an individual or society. (Bidney 1967: 32) Metacultural reality provides the pre-conditions for any cultural processes (Bidney 1967: 160). But Bidney agrees with Aristotle that the logic of power is not primary because creativity and imagination can transcend social environment. Therefore Bidney is 
not a total relativist: rather he has a general theory of relativism integrating all cultural worlds (Bidney 1967: 179).

Bidney comments that as a methodological device, it is frequently useful to abstract certain phenomena for systematic treatment while ignoring individuals and their motivations that were undoubtedly involved. It may be considered appropriate to act and think "as if" certain forms or patterns of phenomena do occur independently of the particular individuals and societies which initiated them. That was also Kroeber's later method but is nevertheless simply a strategy.

\subsection{The fallacy of reduction to a single cause}

In a fundamental statement, Bidney states that only individuals and societies are the efficient cause of cultural processes, which must not be confused with formal or material or final causes and cultural activity of persons in society (Bidney 1967: 33). Culture requires a union of all forms of causality, as opposed to Marxist economic determinism, a fallacy which overlooks the function of man as a selfdetermining agent (ibid.).

Leslie White's work exemplifies the "culturalistic fallacy" (or reductionism or misplaced concreteness), which is committed when he mistakes an epistemic abstraction, such as the number of calories, for an ontological level of reality or autonomous order of nature (Bidney 1967: 107).

\subsection{Nominalistic and formalist fallacies}

Summing up fallacies, Bidney looks to common elements and qualitative novelty. To reduce all qualitative differences to a single kind of reality is also a fallacy of reductionism. The "nominalistic fallacy" is based on the principle of plentitude - the assumption that discrete entities are unrelated to one another. "The implication is that universals are but names, and thus there is no logical basis for relation 
among things" (Bidney 1967: 44). The fallacy of formalism may also assume that forms of beings are unrelated to one another.

\subsection{The relativist fallacy}

The "relativist fallacy" as opposed to the meta-cultural concepts, obscures any cultural processes (Bidney 1967: 188). If one is to agree with Aristotle and Einstein in postulating the fundamental creation of the human imagination, it would follow that man is inherently capable of transcending the limitation of his social cultural environment (Bidney 1967: 179). The impossibilities of cultural relativism as applied to individual cultures are well argued by Bidney (1967: 181). What does a meta-investigation require? It would subsume the basic logical primitive assumptions of the perceived cultural reality, deep cultural norms of any given cultural system and the assumption that ontological factors shaping experience provide pre-cultural conditioning for any cultural process whatsoever. Bidney rejects the antithesis of absolute determinism versus freedom of thought. He holds that "to deny freedom of thought in the alleged interest of science is to undermine the very conditions of the scientific process" (Bidney 1967: 179). The search for any cultural factors that universally unite humans points to one gap between the semiotic investigation as opposed to hypotheses and other studies which do not ask such questions, but in some cases may imply them.

Partly after looking at these problems, I ask what kind of a basic significant unit in human culture shall we have? A cultural unity which impoverishes human life and thought by excluding whole areas of cultural experiences as meaningless may have the virtue of simplicity, but will fail nevertheless regardless of the learned support it may receive. Importantly, "cultural integration [...] is not an unqualified good and [...] everything depends on the nature of the final composition" (Bidney 1967: 182). For Bidney the problem of cultural integration is essentially the harmonizing of diverse polar interests and disciplines, each of which must enjoy a measure of autonomy to 
ensure its own creative advance. This principle of autonomy points to the limitations of logocentrism essentially critiqued by Lotman and Jakobson.

The above summarizes some fallacies, pointed out by Bidney, that have been frequently been a part of anthropological writings. I turn now to examples of articles considering how they relate both negatively and positively to the various principles Bidney described.

\section{Part 3. Ethnological Examples}

\subsection{Bill Maurer: Introduction to ethnographic emergences}

The notable issue of the American Anthropologist (2005, 107/1) that I have referred to, entitled In Focus: Ethnographic Emergencies, is introduced by Maurer's article Introduction to 'Ethnographic Emergences' (Maurer 2005). For Maurer, "world system theory, modernization theories, structural Marxism, and person-centered interpretive approaches offered analytical tools that did not readily fall into the traps of evolutionary or ecological determinism" (Maurer 2005: 1). The author states that "structuralism, hermeneutics, and structural Marxism offered an account of the meaningful words within which social action took place with a rigor lacking in U.S. anthropology" (ibid.). Asserting that anthropology has been going beyond the limits of narrow, traditional anthropology, and into other areas of knowledge for quite a while, however, this is now becoming an extremely conscious cry, apparently. The author seems to have agreed with Sherry Ortner's remark that Bourdieu's practice theory and related others obviated the "stale debates of materialist approaches, symbolic anthropology, and structuralism over causality, and even deeper (but rarely empirical observable) structures" (Maurer 2005: 1).

For Maurer, open anthropology is an inter-relational field that bleeds across its frames. However, the frames need to be understood as metaphorical and porous. Maurer speaks of complex hybrids of nature and culture, for example, the ozone hole story, global warming, or 
deforestation (Maurer 2005: 2). Is hybrid an appropriate term for the interrelation of nature and culture, or local and global, or particular and general, since "hybrid" is in fact the characteristics of all interpenetrating cultural customs and beliefs and biological interrelationships? "Hybrids" are in fact essential for growth and change in culture.

Maurer concludes his article with questionable comfort. He holds that the

point of an emergence is that you do not know where it is going. The point of an anthropology of emergence is not to attempt to achieve the universal language adequate to all transformation, but to go along for the ride, in mutual, open-ended and yet limited entanglements which one might call friendship or perhaps ethnography (Maurer 2005: 4).

But this statement trivializes serious theoretical findings and quests for universals, no matter how difficult the search.

It appears to me that Maurer takes far too rigid an approach to various realms such as biology, socio-biology, natural history, ethics, ethnic sociology, and so forth. The issue of reality does not mean things escaping from their pre-made domains but searching for the complex realities of any particular phenomena which naturally become penetrating areas that are not marked off by man-made domains or frames.

Maurer's answer to the myriad approaches of diversity in culture and nature as a capitulation to entanglement misses the point. Certainly Peirce's abduction and hypothetical thinking, and Crapanzano's imagination, and the Lotman school of interlocking texts and underlying rules and even explosion are not pure chaos but are challenges to further analysis and we are not going along blindly for the ride which trivializes the event.

\subsection{Cognitive anthropology}

Roy D'Andrade's The Development of Cognitive Anthropology (1995) questions the so-called dichotomy between qualitative and quanti- 
tative, favoring the latter. In the forward, the author states that cognitive anthropology is opposed to structuralist, interpretive, and postmodern conceptions of culture. In this summing up, D'Andrade holds that cognitive anthropology is thirty-five years in the making, establishing that culture is knowledge, as was formulated by Ward Goodenough. The aim of cognitive anthropology is to determine the content and organization of such knowledge, and the underlying cultural categories through componential analysis of phonemics and phonetic systems and kinship terminologies. He notes nevertheless that Geertz (1973a: 12) disapproved of the formalizing and quantitative aspects of this approach, referring to the cognitive fallacy as supposing that culture consists simply of mental phenomena.

Going through the various moves in cognitive anthropology studies, D'Andrade tells us how features and taxonomic relations can be approached by means of semantic analysis of various domains such as kin, plants, colors, etc. By 1980, the dominant approach became schema theory in relation to networks concerning the nature of mental representations. This was followed by a study of cultural models and metaphors. Cognitive anthropologists break culture into parts - and develop theories from the pieces of culture. D'Andrade (1995: 247) writes that:

[I]f culture is placed in the mind, then the organization and limitations of the mind can be used to find cognitively formed units - features, prototypes, schemas, propositions, theories, etc. This makes possible a particulate theory of culture; that is a theory about the 'pieces of culture', their composition, and their relation to other things. One has to have a notion of separable units before the study of their distribution has any meaning.

D'Andrade sees the current trend as the rejection of the concept of culture, and substitution of the term "discourse" when referring to symbols and meaning. Rejecting the notion of culture as a single structure "does not imply that there is no reason to investigate culture" (D'Andrade 1995: 251). We need to investigate how society works and the cognitive system - reasoning, memory, and perception. D'Andrade concludes that cognitive anthropology has been able to 
provide reliable descriptions of cultural representations, and a bridge between culture and the functioning of the psyche.

For cognitive anthropology, parts precede the whole, knowledge is privileged and psychological traits serve the needs of the culture carrier in mapping out his or her life. Neglected is the relation to the aesthetic, emotional syndromes, imagination, and creativity and context. Thus the behaviorist heritage still lurks - what you see, feel, smell, and what computational machines can evaluate as valid aspects of the culture's map, are the empirical realities. Different problems not answered by a quantitative approach come to be dropped out problems such as Kluckhorn's values, Kardiner's personality and culture, Benedict's Patterns of Culture, Crapanzano's imagination, and others. What is left out appears to me to be more essential than what is included. A major problem is the method: description, quantification, particularization, ruling out all that may not fall within this rubric, overlooking the integration and interlocking of aspects of the mind and culture which must precede any attempt to divide up culture, which indeed is not stable since interrelations are vulnerable to many aspects of chance, history, and context.

\subsection{Elizabeth Brumfiel: Cloth, gender and continuity and change}

In Elizabeth Brumfiel's article Cloth, gender and continuity and change (Brumfiel 2006), she compares backstrap dash loom weaving in three cultural contexts and historical dimensions - ancient Mayan, ancient Aztec, and $20^{\text {th }}$ century Meso-Americans. Within each group, weaving had a different meaning and function. For example, among the Maya, weaving defined class; among the Aztecs, weaving defined gender and among $20^{\text {th }}$ century Meso-Americans, weaving defined ethnicity.

There is considerable discussion in this article about the background of these functions, and the changes and meanings of the various forms of weaving. The author wishes to find some of the underlying paradigmatic properties of these three elements. She 
criticizes Saussurean linguistics for requiring understanding of a thing by understanding what it is not. This study is primarily a historical and descriptive narrative of three groups of peoples. It does not advance much beyond the referential meanings, and the deeper levels of the aesthetic, the metaphorical, and the poetic are barely implied, but it does at least restore the historical method and the issue of multifunctionality and cultural meanings.

\subsection{Russell Leigh Sharman: Re/Making La Negrita: Culture as an Aesthetic System in Costa Rica and Turner's Remarks}

The main concern of the next article Re/ Making La Negrita: Culture as an aesthetic system in Costa Rica (Sharman 2006) is the question of how meaning is produced in the veneration of La Negrita, the Black Madonna and also the patron of Costa Rica. Both appear as an apparition and an icon. The article argues that meaning is produced and reproduced through the "attachment of value to [...] the experience of worshipping a tiny stone carving of the Madonna and child" (Sharman 2006: 842). According to the author, meaning is rarely shared as it is constrained by social relationships of power. Meaning is considered as produced, reframing culture as an aesthetic system, and is understood as the "primary processes of valuation" (Sharman 2006: 843) as they relate to experience and the re-creation of experience through cultural production.

The author holds that "crucial to this argument is the distinction between the perception of value and the production of meaning as two parts of an aesthetic system" (Sharman 2006: 843) and that "what becomes recreated as socially valued experience in this aesthetic system [...] is rooted in relations of power that are hegemonic in the Gramscian sense" (ibid.). However, according to Turner "agency is not delegated to intellectuals as it is in Gramsci's formulation, it is inherent in the democratic quality of 'an experience', which is able to 'repudiate all pasts"' (Turner 1986 in Sharman 2006: 843). There is a dialectic tension between the immediacy of experience and the media- 
tion of power that forces constant revising (Turner 1986: 36 in Sharman 2006: 843).

As an object of religious worship, La Negrita is both "Other and intimate, producing a phenomenological bracketed experience - a salient moment of religious awe" (Sharman 2006: 844). The article traces the dynamic history of the La Negrita from an indigenous ritual to an instrument of power utilized by the Spanish in nationalist movements. According to the author, "the cult of the La Negrita began as an invention of the church and the colonial state to recognize the growing mulatta population around Cartago" (Sharman 2006: 845). "La Negrita became a black symbol used to further segregate the colonial population" (ibid.). The complex history continues but the argument ends with the following conclusion. "La Negrita exists at the nexus of an aesthetic system where the egalitarianism of experience is always in conflict with the authoritarian meaning [...] Together, they offer a more nuanced understanding of culture as an aesthetic system, and what happens in the space between a significant event and an event of significance" (Sharman 2006: 851).

The author explains culture as an aesthetic system in only a general way. Jakobson was a pioneer in the importance of aesthetics but also of context, multifunctionalism, and multisemiotics, as well as Arnheim and others. However, Sharman's treatment does not concern individual behavior but rather is a history with the exception of a short myth. Dialogue is also not a part of Sharman's depiction - for that we have to look to Bahtin, and others of the present group in Tartu. It is also unclear why value and meaning need to be considered as two separate parts of an aesthetic system.

\subsection{Anthropology: A diplomatic middle way}

Bruce Knauft (2006) considers anthropology in the middle. He believes that negative paradigms need not exist in cultural anthropology. He opposes master theory's reliance on master narratives and history, giving preferred American anthropological examples. Rather, this 
"part" approach is exemplified by mosaics of part theoretical assertions, part historical events, and part activist voices, and does not rely on general theories and paradigms or suggestions about creative and critical combinations. Knauft argues that anthropology is post-paradigmatic. The concept of culture has defuse meanings and therefore the term structure should be cast in the adjectival form, structural. Practice and agency all could be adjectival, as could modernity. Theory is also reduced to theoretical.

Knauft notes that according to Catherine Lutz (The gender of theory, 1995), master narratives were associated with men while an example of the middle ground, of which she approves, is the work of Hertzfeld, who is a man (Knauft 2006: 413). Repeated terms are middle, mid-level, middle ground, mid-range, and intermediate. This article strains to be mainstream. It expresses fear of theory but does not wish to be considered anti-theoretical. It generally rejects history. It appears that clear, accurate, and mindless competition is the model (autism). One must be careful not to tread on non-controversial views, except corpuses of contemporary work. Surely Peirce's fallibilism is far preferable to perfect middle cores. And here there is an example of the sanitizing of a rich field, losing the breadth of human culture. Indeed, in Knauft's writings, culture is no longer a noun, but a mild adjective. Since semiotic studies are inventing theoretical interpretations in the context of history, Knauft's careful method is far afield.

\subsection{Dialogic anthropology and history}

The Dialogic Emergence of Culture (ed. Dennis Tedlock and Bruce Manheim, University of Illinois, 1995) is a collection of essays based on Jakobson's and Bahtin's view that dialogue is a more fundamental form of speech than monologue. Language as a shared system is an emergent property of dialogue. "Once culture is seen as arising from a dialogical background, then language itself is renewable as an emergent cultural (or intercultural) phenomenon, produced, reproduced, and revised between field workers and natives. The dialogical ap- 
proach amounts to a critique of expectation and of interpretive anthropology where the literal conversations are submerged between interpretants and already produced texts" (Tedlock, Manheim 1995: 2).

Jakobson argued that there is no such thing as individual speech without dialogue. Even inner speech "is only an elliptic and allusive substitute for the more explicit enunciated speech. Furthermore, dialogue underlies even inner speech" (Jakobson quoted in Tedlock, Manheim 1995: 7). Thus language as a shared system becomes an emergent property of dialogues rather than being granted ontological priority over speech (Tedlock, Manheim 1995:1). "Cultures are produced [...] in dialogues [...] shared culture emerges from interaction" (Tedlock, Manheim 1995: 2).

The dialogical turn was opposed to the separation of culture from language, but that separation, which began in 1940, only grew worse. In the post WWII period, the authors hold that "language came to be regarded as a secondary representation of independently figured social and cultural forms" (Tedlock, Manheim 1995: 6). White and Bahtin's observation that all discourse is "replete with echoes, allusions, paraphrasing, and outright quotations of prior discourse" (Tedlock, Manheim 1995: 7) has proved to be far more fruitful.

The introduction to Dialogic Emergence of Culture is followed by a collection of essays employing a dialogic model and concludes with a question and answer chapter considering interpretative culture while the notion of "text" is used in various treatments. Notably, the interpretative method of these studies does not employ the Tartu school's "text"1 to any degree in its systematic method that raises questions of

Juri Lotman and his followers paved the road for new paths in contemporary semiotics, labelling their approach "semiotics of culture". A focal concept was the text and I pause here to introduce the background to this term. In 1962, Pjatigorskij defined the text as a variety of signals composing a delimited, autonomous whole. In the spatial sphere it must be fixed, in the pragmatic sphere the text has an inner structure, in the semantic sphere it must be understandable (Pjatigorskij 1971[1962]: 76). In 1970 Lotman described a culture as a "semiotic mechanism for the output and storage of information" (Lotman 1970: 2), and "a historical evolved bundle of semiotic systems (languages) which can be composed 
many forms of signs, universals and underlying values, as does Lotman. Lotman began to perceive cultural behavior as text, not just linguistic behavior. "Text" includes the non-verbal sphere as well as language as quoted in Portis-Winner and Winner (1976), and it became a fundamental significant unit of cultural semiotic systems. Lotman agreed with Jakobson's position on the priority of dialogue which generates language on which the idea of semiosphere is based. "The ensemble of semiotic formations [...] as single, isolated language, is a precondition for its existence" (Lotman 1984: 16). "Dialogues [...] become one of the ontological characteristics of the semiosphere". "All borders", writes Lotman, are bilingual". Thus, concludes Lotman, "the elementary act of thinking is translation, and the elementary mechanism of translation is dialogical" (Lotman 1992: 143).

As far as it goes, Tedlock's and Manheim's collection uses a Bahtinian dialogic semiotic approach. It is a study of verbal behavior and does not consider all possible signs as does Peirce, nor the fact that there exist non-verbal areas of culture, and that sign-like systems exist among non-humans. Nevertheless this study carries us forward.

\subsection{Sherry Ortner: Theory in anthropology since the sixties, comments about power by Eric Wolf}

In general, the important issue of power in meaning and human relations is not sufficiently studied or taken account of. Lukes sees three dimensions of power (Lukes 1974 as summarized in Heyman 2003: 142): in the first one, one party gains the power in open confrontation; in the second dimension, the confrontation is not open, but the opinions of the two parties are conflicting; and in the third dimension

into a single hierarchy (superlanguage) which also can be a semiosis of independent systems" (Lotman 1970: 8). As Lotman wrote, a semiotically evolved bundle of semiotic systems can be composed into a single hierarchy. Later he preferred the term "text" and introduced the concept of semiosphere, the widest area in which sign systems could be extended and could bring about a link to another plane, and semiosphere was followed by the biosphere. 
of power, the governing party shapes the cultural and social framework so that the subordinates show positive support to the superordinates, in spite of their own aims. This last aspect needs to become more transparent for anthropology that studies the semiotics of meaning. As an example, Lukes analyzes various attempts to exemplify power, and particularly the devil and commodity fetish (a ritual) in South America (described in Taussig 1980). I have described Wolf's concept of imagination in the minds of subordinate power-holders (Portis-Winner 2006). In his Envisioning Power, Eric Wolf held that power "is an aspect of all relations of people." He argues that structural power makes some kind of behavior possible, while making others less possible (Wolf 1999: 385). Structural power steps outside the structure (Wolf 1999: 62). It is best seen in a historical, comparative method.

As I have written (Portis-Winner 2006), Eric Wolf calls for some interrelations between the fields of anthropology as early as his 1964 book, Anthropology (Wolf 1964), and repeated in 1974 with some sad reflection, writing that the state of affairs continues. Sherry Ortner writes in her article Theory in anthropology since the sixties (Ortner 1984) that she agrees with Wolfs position, and even refers to the past metaphor of the anthropologist Lowie, who described culture as "shreds and patches" (Ortner 1984: 126) Ortner believes that while anthropology was never united, it has devised some large categories of theoretical applications, arguments, and issues which she does not see as yet substantiated. This problem points to a fundamental gap between contemporary anthropology and the broad goals of the Lotman group. Eric Wolf (1964: 96) writes in his analysis of power, that "the anthropological point of vantage is that of a world struggling to be born". What is worth studying is human experience in all its variability and complexity. His aim was to set the framework bridging the humanities with anthropology. In his last book, he commented that such a synthesis had not occurred; rather there were growing schisms in the field (Wolf 2001: 11). In his preface to Envisioning Power (Wolf 1999), he held that human sciences were unwilling or unable to come to grips with how cultural configurations intertwine with considerations of power. He wrote that his aim was the 
exploration of ideas and power observed in streams of behavior and recorded texts. In this pursuit he also wrote in a private communication that he wished to explore Peirce's third - unfortunately he did not live to carry out this task. He also brought to the fore the oftneglected role of the imagination (Wolf 1999) as the formation of ideology in his discussion of the Kwakuitl, the Aztecs, and the Germans through the Nazi period.

Similar to Wolf, Ortner refers to an "apathy of spirit" since Boas (Ortner 1984: 127). The Boas school began as a revolt against past misunderstandings and issues concerning race and culture and mythological evolution. But on this basis, he called for a new spirit, where race, language, and culture should be reconceptualized, and where the art of indigenous Indian groups should be understood in their own right, styles, meanings. His approach was a combination of humanism and science. Ortner proposes to rescue anthropology from a post-Boas decline by introducing new key terms: symbol, action, or praxis. She states that three movements emerged in the sixties: symbolic anthropology, cultural ecology, and structuralism. She holds that Geertz and Turner were the leaders of symbolic anthropology. Ortner points out that Geertz's anti-theoretical bias and his limiting of the symbol primarily to its referential meaning (which I believe is not quite accurate) are opposed to Turner's position. However, Turner's symbols have many levels and meanings, including roles, religion, and beliefs, and Turner conceives of symbols as more dynamic than does Geertz (Ortner 1984: 129-131). In this sense Turner is closer to a semiotic approach. According to Ortner, Geertz did not analyze types of symbols and was not interested in ethos or culture embodied in public symbols, although he attempted to study culture from the native's point of view, but at times he confused his impressions with the values of the Balinese described. Geertz's approach was limited since it was not based on theory and action. I believe that his call for the native point of view, whether fully successful (which it was not), was his fundamental contribution to a more sophisticated awareness of internal or ethos meaning in culture and contributed to the semiotic effort to explore multiple points of view depending on the context of 
the individual being studied. Margaret Mead had already contributed that anthropologists cannot avoid seeing a culture through their own cultural lens, thus she believed that the observers should try to account for this in their writings.

Ortner points out that Turner did not see society as harmonious integration based on symbols. Rather he saw actors as moving from one status to another, which she held was an active forerunner concerned with pragmatics. But she noted that both Geertz and Turner lacked sound theoretical systems (Ortner 1984: 131-132).

Other movements discussed by Ortner are evolutionary anthropology, ecological and adaption anthropology; she did not note that all of these are useful when not hampered by oversimplications and reductionism. According to Ortner, structuralism was invented by Lévi-Strauss (Ortner 1984: 135), which of course is not true. Structuralism was developed by Jakobson, Mukařovský and others in Prague, and was outlined in their notable thesis, "The Prague Linguistic Circle", and has unfortunately been confused with Russian formalism. Structuralism of the Prague innovation was a rebellion against Saussure's static linguistics and structuralism, since the Saussurean structuralism was not dynamic.

Ortner (1984: 141-144) also highlights political economy which she says sided with capitalism, with some exception as for example the work of Edward Said. Ortner believes, in agreement with Wolf's view but not his spirit, that by the eighties anthropology was disintegrating. But Marxist and political economists continued to dominate anthropology. She was apparently thinking of economic anthropology in this generalization.

As opposed to the disorganized state of anthropology, Ortner concludes by pushing a modern practice theory. The system of practice theory is explained as a seamless whole. According to Ortner (1984: 149), practice is the study of all forms of human action from a political angle.

Practice, then, is the key symbol of anthropology of the eighties. In spite of Ortner's long discussion of anthropological concepts and practices, there is no mention of what I have called the gap. Thus while 
serious biological and physical scientists (and Lotman's semiotics of culture) were grappling with larger and unifying themes - dynamics of change and communication understood as applying both to the non-human and human world - anthropology for Ortner remains a particular form of praxis. This is not to say that Ortner has not commented on some important directions - e.g., by Vincent Crapanzano, Del Hymes, Victor Turner, and others. But her anthropology "since the eighties" leans towards a narrow path. We need a broader and more humanistic and scientific frame, which I shall try to point to as this essay continues. Thus Ortner's disappointing suggestions about the state of affairs from the sixties on are too limited to guide us to adventure into the broadest goals.

\section{Part 4. Recent approaches in interpretation of signs}

\subsection{Geertz and relativism}

Geertz's article Distinguished lecture: Anti anti-relativism (1984) is a defence of his brand of relativism. Here Geertz denies nihilistic implications, without making the argument for the denial. It seems that for Geertz relativism means a benign tolerance but its limits are not drawn in any clear way (1984). In Geertz's Thick Description (1973a: 5) his positions are well summed up:

The concept of culture I espouse [...] is essentially a semiotic one. Believing, with Max Weber, that man is an animal suspended in webs of significance he himself has spun. I take culture to be those webs and the analysis of it to be therefore not an experimental science in search of law but an interpretive one in search of meaning.

Here the rejection of laws for interpretation both approach and distance Geertz's oevre from Lotman's semiotics of culture. Geertz concludes his 1995 study with yet another metaphor, this one borrowed from Bruner's Acts of Meaning (1990: 150), a comment on the most famous Sanskrit drama, Kalidasa's Sakuntala, where the sage 
does not recognize the elephant, only its footprint after the elephant has left, from which he concludes that an elephant had been present (Geertz 1995:167). Geertz remarks that "ethnographic anthropology is like that; trying to reconstruct elusive, rather ethereal and by now wholly departed elephants from the footprints they have left on my mind" (Geertz 1995:167).

Geertz sees this as a critique of post-positivism (Geertz 1995: 1678). This metaphor brings to mind Peirce's example of an index (the footprint), but for Peirce the index is not isolated. It means binarism whether the index is contiguous with its object or operates on the principle of pars pro totum. The index for Peirce does not refer to something wholly departed and indeed if the sign is fulfilled it leads us to thirdness and the symbolic level. In a sense Geertz gives up the battle by assigning ethnography to individual fictions, and facts to mere traces.

While Geertz reminds us (1973b: 448-9) that various notions of "text" since the Middle Ages have freed the term from the confines of scripture and writing, allowing us to see all culture as an "assemblage of texts". Geertz's idea of "text" remains additive and theoretically underdeveloped, and thus "the more profound corollary, as far as anthropology is concerned, that cultural forms can be treated as texts, as imaginative works built out of social materials, has yet to be systematically exploited" (Geertz 1973b: 449). However, the concept of "text" was at the time being thoroughly discussed by the MoscowTartu group.

For Geertz, the purpose of interpretation of culture, or penetration of a text, is limited to discovering its social semantics, and Geertz is not concerned with underlying theoretical organizing principles such as values, norms, world views, or structures, and in fact he dismisses the whole area of syntactics as a subject of investigation. Accordingly, in his Thick Description (Geertz 1973a: 10) Geertz maintains that, "Once human behavior is seen as symbolic action [...] the question as to whether culture is patterned conduct [...] loses sense".

In Geertz's later work, After the Fact: Two Countries, Four Decades, One Anthropologist (1995), anti-system and relativistic persuasion 
predominate, as do cultural performances seen as narration of stories, which was his concluding affirmation in his notable Notes on a Balinese cockfight (Geertz 1973b). As Geertz puts it in his After the Fact, "One is faced [...] with a confusion of histories [...] There is no general story to be told" (Geertz 1995: 2). More specifically, he states that "Floundering through mere happenings and then concocting accounts of how they hang together is what knowledge and illusion consist in" (Geertz 1973a: 3). In his Imaginative Horizons, Crapanzano (2004: 87) decries the resulting emptiness of Geertz's "floundering", and comments that "Ironically [...] the denial of the possibility of a 'real' mimetic account, of any master narrative [...] does in fact announce an overarching master narrative - a consuming obsession with artifice".

\subsection{Turner and performance anthropology}

A key issue in Turner's anthropology of performance is his intense interest in the inner life of the subjects he studied. He stresses the symbolism not only of objects but also of social dramas the roots of which he sees in Greek drama (Turner 1982: 11-12). Turner extends Van Gennep's concept of the liminal to his own liminoid, which refers to the carnival atmosphere in complex societies. Here he is clearly influenced by phenomenology and by Dilthey and prefers the idea of a hermeneutic spiral to that of the circle. His use of montage suggests Jakobson's metonymic metaphor and Turner's social drama, which was of formative importance based on process and dynamics, and suggests Crapanzano's scene, which I discuss next, as well as Bahtin's study of medieval carnival. Turner's complex use of symbols in his study of the Ndembu and other works fundamentally influenced the anthropology of meaning where symbols are immersed in rich rituals and traditional context and beliefs, conscious or subliminal. Turner does not use the concept of "text", nor does he suggest a system beyond interpretation. 


\subsection{Syncretism and the role of imagination}

I turn now to Vincent Crapanzano's Imaginative Horizons: An Essay in Literary-Philosophical Anthropology (Crapanzano 2004), which echoes Wolfs plea (1999) for attention to that almost limitless factor, imagination. The book opens with a quote from Joseph-Marie de Gérando. Gerando wrote that "The imagination is the first faculty that one must study in the savage because it is the one that nourishes all the others"; it is the "first faculty to develop in the individual" (cited from Crapanzano 2004: 7). The collected lectures are devoted to cultural creativity and the particular tensions that are involved in cultural creativity which according to Crapanzano American anthropologists have avoided (with the possible exception of Kroeber). Rather they have spoken in an often "deterministic fashion, of invention, adaptation, syncretism, cultural change, development, and evolution" (Crapanzano 2004: 1). Crapanzano holds that American anthropologists are "more concerned with the products of imagination than with the process of imagination, and that the individual has been slighted" (Crapanzano 2004: 1). He employs Bonnefoy's image of the "arrièrepays" (Bonnefoy 1982; in Crapanzano 2004: 2) the hinterland, as a kind of governing trope. Crapanzano looks at openness and closedness and how we construct horizons that determine what we experience and interpret.

Crapanzano's interest is in fuzzy horizons, "auras" that "always accompany experience and resist full articulation" (Crapanzano 1992a: 2). Once the horizons are articulated they freeze our view of reality "fatally", were it not that a "new horizon emerges and with it a new beyond" (ibid.), followed by a new horizon, suggesting the aftermath, the less violent version of Lotman's explosion. The dialectic of openness and closure haunts Crapanzano. In the book just quoted and an earlier one, Tuhami (Crapanzano 1980), he feels that the attempt is to unmask the ways that ethnographic writings leave their imprint on supposedly objective data, and he considers how power and desire affect ethnographic writings. His books (Crapanzano 1992a; 2004) "play with form and subject [...] and create [...] disquiet [...] and a 
kind of turbulence in the reader" (Crapanzano 2004: 3). In Imaginative Horizons montage juxtaposes the unexpected ethnographic description with romantic poems (ibid.). The aim is "to destroy prejudices, [to] open horizons, and promote creative thought and action" (Crapanzano 2004: 3). Thus the penchant of humans "to reduce the strange to the familiar, the exotic to the banal, or in extremis to eliminate the strange, the exotic and the foreign by violent means" is critiqued (ibid.). He holds that "the reductions are all too often facilitated by academic disciplines that do so uncritically in the name of one science or another" (ibid.).

Crapanzano does not oppose scientific approaches to anthropology as long as they meet appropriate epistemological and methodological standards and acknowledge moral and political implications. But he critiques anthropological approaches and other humane sciences that model themselves on some other science, the subject of which is radically different from that of anthropology. Additionally, narrow anthropologies leave out what may be the most vital. He holds that anthropology has a moral charge: if we dismiss everything a people holds important and reduce their culture to ecology and adaption, or cognitive or genetic or evolutionary schemes, and we promote our own parochialism, we devalue those we study. Also important is what these people say about us. He accuses Americans of complacency arising out of "studied ignorance or indifference" and argues that "anthropology should always be pluralized" because it is essentially "an interstitial discipline" (Crapanzano 2004: 5).

Crapanzano believes his montage design rescues the importance of the individual perspective, for a focus on the general has resulted in distortion, simplification, and determinisim, and has led to the ignoring of imaginative play, creativity, transgressive possibility, and human freedom. He mistrusts both sociological and psychological explanations, considering them as just-so stories or ideologies that offer comfort when we are faced with the confusing, the puzzling, and the "seemingly unknowable" (Crapanzano 2004: 6). He prefers the puzzlement of the montage to easy explanations, process over topography, the temporal over the spatial. 
Each chapter is introduced by a quotation that presents a theme of imagination (body, pain, hope, memory, trauma, transgression, or death). Such underlying discontinuity and disjunction cast in a poetic dimension is often ignored in ethnography. We do our best to deny the high stakes in interpretation, he writes. For example, there is the US-Iraq war, where one response to the challenge is the obliteration of those who pose the challenge. "Despite the [...] reality of terrorism, weapons of mass destruction, oil interests, and paranoid personalities, the projected war is also a Kulturkrieg" (Crapanzano 2004: 11).

For Crapanzano, the objective is enveloped in the subjective understanding. He calls for "self-critical reading understood both literally and metaphorically that resists full closure" (Crapanzano 2004: 11). It is the frontiers as horizons extending into the space-time of the imaginary that fascinates us. Thus he sees imagination through a trope the arrière-pays, the au-delà, and ailleurs - recalling Yves Bonnefoy. Crapanzano translates arrière-pays as hinterland, meaning background, a land or places that are simpler, that are beyond where one is but that are intimately related to where one is. The beyond is like shadows; the beyond slips away only to reappear just when we thought we had rid ourselves of it - reminding us of the literature of Proust, Peirce's infinite regression ${ }^{2}$, and the novel Snow by Orhan Pamuk.

Crapanzano takes us into imaginative vistas never ending. He adds, in his poetic view, whole dimensions more to culture than others have grappled with, but compares with Eric Wolfs imaginative ideologies, and Orhan Pamuk's imagination of other worlds.

Like Peirce, Crapanzano holds that although dialectical models of self-constitution conceptualize the process in dyadic terms as between self and other, such models must be understood "in triadic terms". He

\footnotetext{
2 Peirce defined the sign as something which stands to somebody for something else. The sign was composed of a first, iconic (similarity, artistic), a second, index (contiguity, struggle), and a third, symbolic, in which the relation to the object is conventional. All three levels compose the symbolic sign, which was hardly limited to its referential meaning. Peirce's third, or context, was ever present and was of the order of rules, norms, traditions, ways of perceiving time and space, basic values, and as such, poses some similarities to Crapanzano's "background".
} 
states that the Western characterization of the self reflects our strong emphasis on the referential role of language at the expense of the pragmatic (Crapanzano 1992b: 94-95), and notably, at the expense of the aesthetic and the metalevel of analysis. Crapanzano finds that ascriptions of the self and other can be metapragmatic ascriptions that describe pragmatic features and are expressed metaphorically. The term meta-pragmatic and the problem of higher semantic authority in a dialogue were Bahtin's innovations and were then taken up by Crapanzano.

Like Bahtin, for Crapanzano, all ascriptions of self and other have a commenting and double role. Frequently, in dual, multi-ethnic cultures there are strange juxtapositions where the trope to be read suggests Bahtin's dialogue, Lotman's montage and Jakobson's montage and metonymic metaphors. It also echoes Peirce's auto-communication, exemplified by his story of the child who unwittingly touches a hot stove and learns that non-ego is signaling to ego - and is the sign of consciousness of self as other, in other words auto-communication.

In his afterword to Manganaro's volume, Crapanzano holds that "the post-modernist proclamation that master narratives are dead [...]" puts "into question the taking of (and justifying of the taking of) an extra-textual stance of accepting the narrative" (Crapanzano 1990: 303).

For Crapanzano a focal issue today is the fate of the authoritative function which he calls the Third. Crapanzano sees this function as a guarantee of meaning mediating any interlocution and as technically being a metapragmatic function and clearly not mere fiction.

The Third may be symbolized [...] by such notions as the law, conventions, reason, cultural tradition, language, [etc]. It may be embodied by father, king or priest [...] by spirits, deities and even by a third person (the audience) in any dyadic exchange [...] When the Third is simply an empty function, there can be no communication (Crapanzano 1992b: 90).

Here Crapanzano invokes Peirce's mediating Third, the symbol which is never empty but is based on reflection and relationships and also 
invokes Bahtin's “double-voiced words", where the speaker inserts a new semantic orientation which already has - and retains - its own orientation (Bahtin 1981: 156 in Crapanzano 1992b: 93). Crapanzano notes that where the commitment to the egalitarian pretense is very strong, it well may be that no participant to the exchange may willingly admit that his recontextualizing response to the other has higher semantic authority. It is this meta-parodic situation that resembles the discourse of the post-modernist's postulates (Crapanzano 1992b: 94). Such parodic situations are pertinent also to present-day politics. For example, under communist regimes, in Poland, there was an active dissident industry studying "double speak" - the unmasking of the double meaning and egalitarian pretense conveyed by official statements. Indeed, notes Crapanzano, traditional empirical approaches have ignored the mutual change that occurs in a dialogue (Crapanzano 1992b: 98).

Crapanzano asks what is happening today to memory, and by extension to history; and does not this vacuum lead to the defenselessness and even attraction to fundamentalism (Crapanzano 1992a: 99)? He leaves us with the question whether we can recapture the Third and, drawing on Benjamin, Crapanzano asks if one erases but does not expunge, would this erased miracle be the return of the Third, our western hegemony - and the capacity to escape meta-parodic indeterminacy by knowing whose parody is empowered (ibid.)?

\section{Crapanzano's The scene}

Crapanzano writes that he explores the relationship between objective paramount reality and its subjective, shadowy world, "edging on the imaginative, which I call the scene", suggesting the two interplaying realities and "our present take on the 'empirical' has led us to ignore this dimension of experience" (Crapanzano 2006: 387). He calls attention to the "intersubjective nature of subjectivity itself and offer a preliminary attempt at understanding the complex interlocutory-the indexical-dramas occurring in ritual, for example, psychoanalysis and 
anthropological research, that constitute the scene" (Crapanzano 2006: 387).

He finds that we ignore or reject the romantic or "the 'subjectification' of the putatively objective contexts [...] of the phenomena we observe" (Crapanzano 2006: 388). He differentiates between objective reality and what he calls the "scene". Crapanzano argues that "subjectivity [...] is essentially intersubjective", mediated through language and immediately through encounters (Crapanzano 2006: 389). The scene colors and intones the objective. It is the objective reality that gives us epistemic if not ontological security. We could speak of the scene, says Crapanzano, by analogy with double-voicing, as double sighted, like suggested by Bahtin's world. How the scene is framed by the situation in which one finds oneself affects how one responds to it or even ignores it (Crapanzano 2006: 389).

Crapanzano (2006: 392) describes a communion service in an evangelical church, a ritual that he compares to Turner's (1974: 94) communitas, or Durkheim's social effervescences at the core of primitive rituals. Crapanzano suggests such rituals express loneliness (as opposed to communitas). Ritual studies may be felt as miraculous, mystery, and the uncanny having no real referent. Crapanzano, being a rationalist, needs to account for the miraculous. He stresses that "the paradoxical relationships between contingency and repetition - a repetition that both enhances the contingent as it disarms it" (Crapanzano 2006: 394). He argues that one finds oneself in the synchronic present and the diachronic past "that affords interlocutory possibility" (Crapanzano 2006: 395). Here I see reverberations with Jakobson's metonymic metaphors (continuity, metonymy, and repetition) while metaphor is the rejection of the dichotomies of synchrony and diachrony in favor of similarity (Jakobson 1960).

Crapanzano asks why we cling to empirical reality, "why has that reality become the bulwark of an epistemological discipline that, despite its rejection of any ethical foundation, is carried out with such moral rigor" (Crapanzano 2004: 398)? He explains that he is not making a plea for the irrational but rather "for an opening of our empiricism to include within its purview the irrational - the less than 
rational" (Crapanzano 2004: 396). Crapanzano explains how do "interlocutory exchanges precipitate the scene, if not paramount reality [...] the relation between scene and reality". (Crapanzano 2004: 398) In many cultures memory and reality are conceptually confused but latent interlocutors are never wholly absent (Crapanzano 2004: 399). "There are times when the indexing of the scene may so mask the indexing of paramount reality that reality slips away" (ibid.).

In Crapanzano's words, "We should discuss the social construction of the way scenes and realities are related or not related to one another" (Crapanzano 2004: 398). We need to consider the way "in which interlocutory exchanges precipitate the scene and [...] the relationship between the scene and reality" (ibid.).

He asks how scenes and paramount reality are constructed. The answer is that it is the result of indexical play between interlocutors, which can be a struggle, and may include memory. Such scenes also index the context. The indexical may be double since it points to what it is, the context, but also to what it is not - the reality - indexing reality slips away. The intersubjective analytical third means that two interlocutors become subjectively united (Crapanzano 2004: 402). Crapanzano does not attempt to propose underlying values that may have universal application, as does Lotman. Nor does he deny the issue. But his relation to Lotman's later works, possibly intertextual, is marked and of great interest.

Crapanzano's references frequently to psychoanalysis. His Third, is clearly a broader aspect of Peirce's Third, with all its varied meanings that rule or control the meaning of signs (Crapanzano 2004: 400). 


\section{Part 5. The post-modern detour}

\subsection{What "post-modern" means}

Bidney rejected total relativism regardless of how difficult and unsuccessful is the search for universals. However, this post-modern view leads us to the general questioning of traditional methodology. The post-modern trend in ethnology had its beginning, some say, as early as in the sixties (Rabinow 1986). There is one area at least upon which there is general agreement, namely that post-modernism is a reaction to the disillusionment of modernism with the rationalism and optimism that has dominated Western thinking since the Enlightenment and the sense that accurate representations are not possible. They are infected with and rooted in relations of power. But such a negative view is not shared by the semiotic world. Accurate representations are imperfect but the goal is not impossible and should be a central aim.

What post-modernism means is a reverberating question, and in a positive sense it directs us to a questioning of ethnological methods, alerting ethnologists to the fact that they are writing stories, and that the written narrative cannot directly mirror the raw data since it is infected with the ethnologist's own perspective, and furthermore from the point of view of the actors themselves there is never a unitary point of view or voice, which is also the message of Bahtin's heteroglossia.

One effect has been the severe reassessment of the writing of ethnology itself (Clifford, Marcus 1986). Some go so far as to advocate that writing relies on self-critical reflexivity, free floating signifiers loosened from their signifieds, pastiche, montage, tropes, dialogue, heteroglossia, quotation, traces, as opposed to history or memory or even nostalgia. Additionally, important to post-modernists are the notions of meta-commentary, allegory and irony, critiques of other ethnological writings, revised conceptions of the other as a dynamic part of the depiction, and avoidance of an absent ethereal voice, reliance on rhetoric and also on a journalistic mode. But this raises the problem that ethnological studies are seen as a kind of fiction, as 
plotted narratives and thus relative and unique. Then comparisons between cultures (one of the guide posts of anthropology) are not useful. Rabinow (1986) and Crapanzano (1990, 1992b) reject the reduction of ethnological studies to fiction, rhetoric, or journalism, and insist on inclusion of context, history, and power relations. They reject total relativism that rules out even the most abstract invariables and thus the view of incommensurability of cultures.

The journal Cultural Anthropology, founded in 1986, opens with the following remark by its editor, Marcus (1986: 3): “A particular model of theory and practice has been disrupted - that of the paradigm, described by Thomas Kuhn, in which research proceeds under a regime of a recognized set of problems and networks". While Kuhn's insights into the difference between cultural paradigms are very valuable (Kuhn 1996 [1962]), he also falls into the trap of incommensurability since each paradigm is viewed as unique and having nothing in common with its part.

In his introduction to Perilous States, Marcus (1993: 1) calls for a manner of writing more evocative of journalism. He is concerned about the ferment in cultural studies, and is searching for new and immediate ways for contact and understandings, and contrasts his suggestions with what he calls "text-based practices of analysis, preferring a more immediate form of reportage since such a mode, he senses, will also address the documentary impulse of cultural studies with its hypercriticism of representation (Marcus 1993: 3). Thus Marcus believes that he is escaping from textualization and that anthropologists' tendency to rely on "rational, detached reflective reason" hinders "more direct access to other's situated frameworks and discourses" (Marcus 1993: 4). However, a semiotic approach to culture, diverse as it is, takes a distinct path from past evidence. It does not reject history, reason, rationalism and detached reflective reason, and defends direct access to data.

The following are some remarks by Crapanzano about the postmodern position. The post-modernist prediction that meta-narratives are dead does not prevent from taking an extra-textual stance. "It does put into question the taking of an extra-territorial position of 
accepting the narrative" and "[...] the move to the meta level is [...] the foreclusion [...] of the purported subject matter of the commentary" (Crapanzano 1990: 303). The original subject, in this view, "becomes an empty signifier that serves a pragmatic function - the preservation of the metaframe, or, in the now fashionable questioning of that frame, the metaframe" (ibid.). Going farther, Crapanzano observes that the writing school of ethnography has created or conferred its own canon (Crapanzano 1990: 303). For the dichotomy fiction/nonfiction is itself a historical and culturally specific opposition involving particular notions of narrative and representation. Ethnography is not simply description but is comparative. It has a creative and epistemological effect (Crapanzano 1990: 305) and the ethnographer may be likened to a trickster without the modernist irony (Crapanzano 1990: 306). Abandoning the ethereal authority in experimental ethnography is only an illusion. "It has its own appeal. It precipitates (its) reality. Text and reality are always implicated in each other and appropriate anthropological distance must be maintained" (Crapanzano 1990: 307). Crapanzano's analysis of reality and rejection of total relativism echoes the mind-set of Searle, Lotman and his group.

As Crapanzano comments, the "barren artifice" as is invented by the post-modern writers is structured like parody and argues it "both incorporates and challenges that which it parodies" (Crapanzano 1992b: 87-88). He notes that most post-modern definitions are vague, contradictory, and general (Crapanzano 1992b: 88) but they frequently stress reflexivity carrying this position so far that there can be no external vantage point. "We are caught within the play of arbitrary signs that are loosened from their referents and no longer systematically constrained by grammars of style, say, or narrative. [...] The concatenation of signs becomes an ironic montage (Crapanzano 1992b: 88).

\subsection{Searle's critique of post-modernism and relativism}

In his book, The Construction of Social Reality (1995), the philosopher John Searle analyzes reality, questioning the post-modern critique of 
cultural research. Searle considers the status of objective facts that are only facts by human agreement, existing only because we believe them to exist, to be real, not fiction. A five dollar bill, a piece of property that we own, are some examples, in contrast to Mt. Everest, the existence of which is independent of human experience. Thus institutional facts, dependent on human agreement, are contrasted to non-institutional facts, namely brute facts.

Searle (1995: iix) wishes to defend and further the position that there is a reality totally independent of us (Searle 1995: 2). He abandons dualism of mind/body. Mind is a higher level feature of the brain and is both mental and physical. Culture is constructed of nature. Searle distinguishes reality from theory of truth which is a complex, philosophical argument based on his theory of correspondence which we cannot outline here. Lotman also grapples with what Searle calls truth, how the brain functions, and how it relates to concepts of time and space and worldview. Searle explains that with consciousness comes the possibility of intentionality - that is, the capacity of the mind to represent objects and states of the world other than ourselves (Searle 1995: 7).

\section{Searle's concept of "background"}

The concept of "background" for Searle refers to the set of nonintentional or pre-intentional capacities that enable intentional states to function. "The key to understanding causal relations between structure of the background and structure of social relations is to see that the background can be causally sensitive to the specific beliefs or desires or representations of those rules" (Searle 1995: 141). "Background" can be compared to Crapanzano's "scene", since here, too, memory and background are causative and knowledge and abilities that are generally known are not part of intentionality "but are the necessary preconditions for the functioning of intentional concepts" (Searle 1995: 133). Background functions in facilitating linguistic interpretation and perceptual interpretation that are extended to 
consciousness. According to Searle "the understanding of utterances and the experiencing of ordinary conscious states requires background capacities" (Searle 1995: 135). Crapanzano shows that from background to intentional states it is not necessary to involve rules since the latter may be unconscious dispositions. This general view of the flexibility of rules may be related to innovative and creative behavior about which Searle hints in some comments in his book.

This is a defense of context and unconscious underlying norms or dispositions that are formative in creating culture. Those who do not agree with the autonomy of cultural realism, and who hold that reality is but a social construct such as anti-realism, versions of post-structuralisms, deconstruction, according to Searle, are taking positions against all common sense views (Searle 1995: 15).

Searle's importance for culture is the systemic support of the social reality that cultural system, beliefs, and norms share, as opposed to the post-modern position that such cultural habits and practices are pure constructs. Lotman's and Wolf's positions are of course congruent with Searle's, as is also Crapanzano's emphasis on imagination and the aesthetic that also have a place in cultural reality. This leaves the question of the individual creator who is not understood perhaps even in his lifetime, but understood long after. We must assume that the individual creator is constructing some aspects of social reality for the future if his creation is eventually to be understood and interpreted by some other.

\section{Part 6. The semiotics of culture and its roots and evolution in the $21^{\text {st }}$ century}

\subsection{Boas as the beginning and his unending relevance}

To set the parameters, I quote Baker's view that Boas took us out of the ivory tower. Baker discusses the ways Boas' writing and research a century ago is being deployed and used in today's "public arena" (Baker 2004). 
I look at Boas as a crusader unlimited by time-based chronology and by space. I also consider Boas' import as largely misunderstood even today as he does not receive the attention he should. He was at home in all fields of anthropology and more. In his book, Change in Bodily Form of Descendence of Immigrants (Boas 1912), Boas demonstrated that head size was significantly determined by environment (Stocking 1974: 180-90, cited in Baker 2004: 1). Boas' ideal laboratory was the diversity of immigrants and their exclusiveness as workers in Manchester's factories. Although he was attacked for this finding, holding that the results were genetic, Boas' findings have been established as correct.

In spite of enemies and popular anger, Boas succeeded in presenting a paper at the 1911 AAAS, entitled Bases of Primitive Man where he held that there were no pure races, and intelligence tests were fallacious and misleading. He also demolished "false arm-chair" evolution in relation to art and language. He fearlessly destroyed anthropological myths and showed that his empirical method demonstrated facts as opposed to fairy stories. He did not uphold static theories and held that events moved with the times. American anthropology began in a hectic mantra, and Boas' path-breaking positions are important today and have no end. Though he was incorrectly criticized as being anti-historical and anti-theoretical this was not at all justified. His Mind of Primitive Man (1911) and Primitive Art (1927) have become classics. He held that art in various forms was universal and he did not move on linear evolutionary tracks. Similarly, Levi-Strauss found that science in primitive societies was also universal but did not follow an exact path and was based on local factors in the environment and bricolage, simply what was available to the creative mind.

After Boas as well as his leading students, Benedict and Mead, there was a period of general neglect of its famous founders. Since anthropology settled down to descriptive and incorrect evolutionist theories, with the partial exception of Kroeber, following the Boas period, there was a general fragmentation and decline in anthropological scholarship, but later also some explorations and new direc- 
tions, which I have described (Geertz, Crapanzano, Turner), and which suggest interrelations with semiotic approaches.

I turn now to some fundamental concepts of semiotics of culture and recent developments in semiotics.

\subsection{Deely sees semiotics for the twenty-first century}

His study outlines

A unified treatise laying out the basics behind the very idea of semiotic inquiry in general, a treatise providing a map of semiosis as an integral phenomenon (it being understood that semiosis is but the name for the action of signs, which provides the common subject matter for the whole range of inquiries covered by the umbrella term "semiotics" (Deely 1990: xxix).

Kull (1990: ix-xxv) quotes Deely who states that knowledge is definitely in the twenty-first century in the post-modern age. Kull points out that semiotics may be defined in multiple ways. He traces historical developments before Peirce and Jakob von Uexküll and important earlier traces. According to Kull, Lotman believes that semiotics is not meant for those not familiar with some other field of study. Some see semiotics as binding together the methodologies of the humanities and all theoretical bases for all qualitative approaches and as the emperor of all quantitative science such as physics.

The Theses on the Semiotic Study of Cultures as applied Slavic texts (Uspenskij et al. 1973) which laid out broad new programs of the Lotman group, outlined the development of semiotics toward diversity and heterogeneity (Uspenskij et al. 1973: 4). It contains the following formative statement:

The pursuit of heterogeneity of languages is a characteristic feature of culture. Heterogeneity, in its turn, enables us to perceive scientific analysis not just as departing from a single unified viewpoint, but as consisting of a system of perspectives within which each scholar who studies culture has to start by explicitly identifying his or her point of 
departure. The disciplines and scholars studying culture therefore constitute a heterogeneous collection of viewpoints within which efforts have to be made in order to relate different perspectives to one another, to allow them to interact and to unify them methodologically. As a semiotic system, research will at some point develop a need for a generalized description of itself. (Uspenskij et al. 1973: 20)

In Lotman's words, “The highest form of structured organization of a semiotic system is the phase of self-description. The process of description itself completes structural organization" (Lotman 1996: 170). If this structural organization does not cause stagnation, but retains its natural diversity and prospects for further development, as exemplified by Deely's book, then organization means movement towards understanding and change.

In his article Humans and signs (1969), Lotman writes the following:

It [science] often takes that what seemed so simple and clear and discovers complexity and uncertainty there. Science does not always make the unknown known, it often behaves in a completely opposite manner. In the end, science does not always aim at providing as many answers as possible, instead if departs from the assumption that the right way of posing the question and the correct course of argument embody greater value than ready-made answers even if they are right but have not been controlled (Lotman 1969: 6).

The article concludes with some semiotic issues. Following Peirce's idea of synechism, semiosis can include lifeless processes according to Deely (1990), reflecting emergence of later scientific theories beyond Peirce's lifetime and discussed by Eco and Sebeok, holding that this discussion must be left open (Lotman 1969: 4).

This discussion leads us to touch on biosemiotics which I only briefly describe since it is beyond the purview of this study, but which is ineluctably a part of semiotics of the hemisphere so I digress here to look at this issue. 


\subsection{Global semiotics, biosemiotics}

The concepts of the semiosphere and of global semiotics according to Kull, Petrilli and Ponzio and the implications of Lotman and Deely, bring us to the complex area of biosemiotics. What is biosemiotics? Hoffmeyer writes:

It was only in the last decade of the twentieth century that the words began to proliferate in the international literature (Sebeok and UmikerSebeok 1992). According to the biosemiotic perspective, living nature is understood as essentially driven by, or actually consisting of, semiosis, that is to say, processes of sign relations and their signification - or function - in he biological processes of life. (Hoffmeyer 2008: 4)

According to biosemiotician Claus Emmeche:

Biosemiotics proper deals with sign processes in nature in all dimensions, including (1) the emergence of semiosis in nature, which may coincide with or anticipate the emergence of living cells; (2) the natural history of signs; (3) the 'horizontal' aspect of semiosis in the ontogeny of organisms, in plant and animal communication, and in inner sign functions in the immune and nervous systems; and (4) the semiotics of cognition and language. (Emmeche 1992: 78)

Thus, signs do not distinguish between nature and culture. Living systems originate in molecular processes but molecular processes cannot be exhaustively described in chemical terms. This position is anchored in the evolutionary philosophy of Peirce. There is the issue of whether lifeless phenomena are also a part of the semiosphere which is debatable (Hoffmeyer 2008: 5).

According to Hoffmeyer, early advocates of biosemiotics investigation also included Jakob von Uexküll (1864-1942), and to some extent concepts of Bateson (1904-1981).

The article Bioethics, semiotics of life, and global communication by Augusto Ponzio and Susan Petrilli (2001) proceeds to other dimensions. We see the extension of semiotics to the global sphere, we "must accept the responsibility of denouncing incongruities in the global 
system, any threats to life extending over the entire planet inherent in the system" (Ponzio, Petrilli 2001: 263).

According to Ponzio and Petrilli, bioethics belongs to two totalities (Ponzio, Petrilli 2001: 263), the semiosphere and global communication, and the biosphere. The writers call for viewing bioethical problems in socioeconomic contexts that is global communication production (Ponzio, Petrilli 2001: 263). They extend Lotman's semiosphere to include the biosphere, or semiobiosphere, and semiotics of life (Ponzio, Petrilli 2001: 264). They see globalization as tantamount to heavy interference by communication and production to life in general (Ponzio, Petrilli 2001: 268). It is destructive (Ponzio, Petrilli 2001: 269). They outline the now well-known deterioration of the riches of the planet, the dangers of human life.

Petrilli and Ponzio have written widely on semiotics of culture expanding on the thesis of semiotics of life, carrying semiotics to a new level, that of relevance and application to the world, ethics and political consciousness, and this must be continued. This is a most important contribution. We need to view bioethics in the context of global production and communication. They are related from the point of view of ethics. They point to the destructiveness of the universalization of the communication in the production system market which impedes and distorts communication. It destroys traditional cultural practices held in the way of development. This article brings up the problem that ethics cannot be limited to exploitation and economics, but mental suffering, including the effect on the arts and literature.

\section{Kalevi Kull}

Kull in his article Semiosphere and the dual ecology (2005a) compares two types of sciences: semiotics and physics. Physics studies a single, physical reality repeatedly and whereas there are many semiotic realities that are looked upon as brought upon by one individual, they are unique. The semiosphere is defined as the space of qualitative (in- 
commensurable) diversity (Kull 2005a). Therefore, there is a paradox. Diversity, a creation of communication, can also be destructive to excessive communication. Kull quotes Hoffmeyer (1999: 153; in Kull 2005a: 176), "model building is at the core of semiotics and natural sciences. Models are the sum of their building blocks but are [...] complex signs occurring in organisms". Kull argues that "understanding from a semiotic point of view [...] requires instead a continuous interchange between contradicting models" (Kull 2005a: 176).

There is a problem, however, with this position since cultures may be partially incommensurable but hardly entirely - which is one of the basic studies in ethnology. The underlying unities may be too abstract for sign theses but nevertheless, they must be investigated. The solution to the paradox is in Socrates' dialogue, Kull argues.

Kull tells us that according to Lotman's formulation, there is always more than one text and more than one code. Code duality is a basic feature of the semiosphere, a term that refers to "the space of meaning generation" (Kull 2005a: 177). There is only one way to create meaning and that is via multiple simultaneous descriptions (Kull 2005a: 177). Semiosphere is the region of multiple realities and multiple worlds (Kull 2005a: 180) that together form one single reality. Both physics and semiotics are types of descriptions (Kull 2005a: 182). Both aim to study everything in the world and any phenomenon can be studied both physically and semiotically. Semiotics is the study in terms of semiotic space and emerging meanings (Kull 2005a: 182).

\section{Diversity}

Kull argues that following Gregory Bateson, information is "difference that makes a difference. Semiosphere is where distinctions occur or where distinctions are made. Thus, semiosphere is the space of qualitative diversity" (Kull 2005a: 179). One difference between the human and the non-human world is the interest in survival. Organisms cannot be aware of their own death (Kull 2005a: 185). Com- 
munication is the creation of diversity, but too much communication leads to the loss of diversity (Kull 2005a: 186).

Diversity is the power of evolution. Thus, according to Kull's Semiotics is a theory of life (2005b), biosemiotics as an approach to the whole living world begins with Darwin's Origin of Species (1859) but it has medieval roots. He replaces Darwin's model of the tree with a new model - the web model (von Uexküll, Wesiack 1997).

In Kull's Copy versus translate, meme versus sign (2000), Kull shows that biological events at the lowest common denominator are not static. As opposed to standard copying in biological genetics, biological development involves change in usage of the gene (Kull 2000: 4). Epigenetic can be first and gene shift follows. This is not natural selection, since the organism itself selects the appropriate genetic functional genome which will be later fixed by stochastic genetic processes (Kull 2000: 4). Kull writes that according to Stanley Salthe and David J. Depew, development, not evolution could be considered as the central framework as biology; natural selection contrasts with evolutionary development.

\section{Translating or interpreting the genotype}

As Kull continues, if the phenotype is further used for production of the next genotype, then the phenotype is a process, a developing organism. "The genome does not determine the phenotype, but [...] the organism interprets its genome when producing phenotype" (Kull 2000: 7). Emergences of new features of organisms can appear due to changes in inheritance or system or environment. It is not DNA that specifies the feature of the organism. Identical DNA may vary in gene expression (Kull 2000: 4). This is a far more dynamic turn on the traditional genetic system contributing to complex change which is central to semiotics of culture. Bringing the discussion into the domain of semiotics of culture and discussing Lotman, Kull contrasts the non-textual and the textual approaches (Kull 2000: 10). Text is not a structure but a process, and has semiotic features more fundamental 
than a message, which could at times be just simple organic or inorganic molecules. Historicity, intentionality, and intertextuality are features of all texts. Signs are seen as living entities and semiosis is identical to the process of living. Sign or text is always connected to a living system. Culture is a living system. Culture is also a text, according to Lotman, but never a single language. Culture is composed of a complex of texts (Lotman 1984).

Memes, copying a term used by Peirce, are degenerate signs. They can only be copies. Objects of copying are memes. Objects of translation are signs. Darwinian fundamentalism, according to Steven J. Gould, is neo-Darwinism. We need both sides - natural selection biology (copying) and semiotic biology (translation). There is no border between the semiotic and the non-semiotic world. The aim is to find steps between the worlds. Signs grow. Living systems have "aliveness".

\subsection{Concluding remarks - Lotman the Maestro}

Torop's article (2005: 159-170) on the semiosphere contains much information about Lotman's book, Culture and Explosion (2009), which has just become available in English. I will discuss what we know about Lotman's last book in reviews and quotations as stated in Torop's article, as well as comments in other Lotman publications. Torop holds that "The Semiosphere [...] brings semiotics of culture into contact with its history [...] and with the newest phenomena in culture" (Torop 2005: 159). According to Ivanov (1998: 792), "the semiosphere is placed between the biosphere and the noosphere". According to the review of Lotman's Culture and Explosion, "A shift in the paradigms of the semiotics of culture" by Deltcheva and Vlasov (1996: 148-152), the semiosphere is both based on an object and a metaconcept. "We live in a world based on the conjectural unity of two models" (art and science) (Lotman in Torop 1999: 13-14). As Lotman writes, "no method of description rules out another method of 
description. It is as if their reciprocal tension creates a third point of view" (Lotman in Torop 2000: 14-15).

According to a conversation with Lotman that Torop quoted, Lotman held that "the fate of people, history, accomplishments of science is unpredictable. [....] Unpredictability [...] whose mechanisms is one of the most important objects of science, introduces into science a totally new manner, the component of art" (Lotman in Torop 2000: 16).

As I've noted, after Boas, history was largely neglected for a long period. Yet, history does its part in the dynamics of culture. Here one thinks of Wolf, also Kroeber, but Kroeber's history was isolated from the full meaning of culture as long as he separated nature and culture. The impoverishment of history is partly owed to the functionalists, such as early Malinowski, and the misunderstanding and misinterpretations of Boas. Boas insisted on empirical grounds for history. Obviously it was difficult to obtain historical data from primitives who were nonliterate, but Boas searched for evidence of historical data when he could through memory, ritual, and life passage events, etc. He rejected the pseudo-evolutionary history of the followers of Morgan, and the misunderstanding of Darwin, which was an important critique of American anthropology.

Lotman saw film as an important dialogical and dynamic area for semiotic studies (Lotman 1976). He detected a system of distinctive features in film, and attempted to analyze the text on the basis of markedness and unmarkedness. In his article, Cultural semiotics and the notion of text, Lotman replaced the text with the notion of communication, communication between addressee and addresser, between the audience and cultural tradition, between the reader and his or herself, between the reader with the text, between the text and cultural tradition (Torop 2005: 167). Discussing cultural dynamics, Lotman saw cultural language as interwoven into discrete and continual entities (iconic and spatial dynamism). According to Lotman, meaning generation is the ability of culture as a whole and its parts to avoid trivial texts that are to a certain degree already predictable (Lotman cited in Torop 2005: 169). 
According to the reviewers of Lotman's book, Culture and Explosion (2009 [1992]), culture as a "semiotic construct cannot only be observed and described but also governed and guided" (Deltcheva, Vlasov 1996: 148). Culture as a modeling system can influence external reality. They point out that there are two issues in Culture and Explosion, one the relation of statics and dynamics, and the second the relation between system and beyond the system (Deltcheva, Vlasov 1996: 148). To what extent can the cultural sphere correspond to the world beyond its boundaries, the world of nature, and to what extent can one transpose "the conceptual world of language system onto language-independent reality"? (Deltcheva, Vlasov 1996: 148). For Lotman, it is necessary to have at least two languages to carry out this exploration. "Evolution in the cultural semiosphere has two basic manifestations, continuous and punctuated. Continuous can be defined as premeditated predictability" (Deltcheva, Vlasov 1996: 149). Explosion is characterized by unpredictability and sudden change, and can coexist also with gradual evolution. Information is conceived at a moment of explosion. (Deltcheva, Vlasov 1996: 149).

According to Lotman, it is possible to conjoin the unconjoinable under the impact of some creative tension either rationally or emotionally beyond the domain of logic. The rational-irrational side of creative tension exemplifies the complex interaction between translatable and untranslatable, facilitating the penetration into extra-lingual reality. Extra-lingual reality acquires the status of "absolute truth" to its culture carriers, yet we ascribe to language lies (Deltcheva, Vlasov 1996: 149). At some point they are reinstated into the semiosphere as new structural entities (Deltcheva, Vlasov 1996: 149).

According to the reviewers, art, as a primary building block of culture, functions as a domain of freedom, making the impossible possible. Furthermore, Lotman's model of evolution "in which the unpredictability of the extra-temporal explosion is constantly transformed in human consciousness into the predictability of the dynamics it generates and vice-versa" (Lotman 2009: 158). There is no final goal, the universe is inexhaustible. 
At the center of the model he positions the Creative personality conducting a great experiment, the results of which are unexpected and unpredictable even for the Creator. This approach allows us to perceive the universe as an inexhaustible source of information. (Deltcheva, Vlasov 1996: 151)

In opposition to the linear model, Lotman introduces a third apex which compensates the tension between the two existing extremes and transforms it into a volumetric structure. The transformation of the two-dimensional plane into a three-dimensional semiosphere expands the areas towards which the development of culture can be oriented. (Deltcheva, Vlasov 1996: 151)

There is a constant interaction between culture and extra-culture, the semiosphere and the extra semiotic space. Lotman "presents a functional perspective on culture in its dependence on space outside the boundaries of art" (Deltcheva, Vlasov 1996: 149). The reviewers state that naturalization of a foreign cultural element is complicated on the level of language through the mechanism of naming (Deltcheva, Vlasov 1996: 150). Explosion does not mean infinite potentialities. Gradual evolution is not static either. Gradual explosion generates new meanings.

There is an alternation between explosion and gradual evolution. Art is a reflection of reality (Hegel's positivism). On the other hand, art as an antithetical life (neo-romanticism) embodies antinomy: art "makes possible not only that which is forbidden but also that which is deemed impossible" (Lotman 2009: 150). Lotman also asserts that the relation aesthetic/ethical is the basic model of culture. If the aesthetic approach rejects the ethical reading of art, the ethical reading becomes more stable. The relation between aesthetic and ethical, or between art and morality, is the basic model of culture. The

very resolution, with which aesthetics denies the inevitability of the ethical interpretation of art; that very energy, which is expended on similar proofs, is the best confirmation of their stability. The ethical and the aesthetical are opposites and are inseparable as the two poles of art. The relation between art and morals echoes the common fate of oppositions in the structure of culture. (Lotman 2009: 151) 
The individual, through art, can experience the artistic world as a mental experiment in which the forbidden zones of reality can be inspected. "A sharp increase in the level of freedom in relation to reality makes art an experimental pole. Art creates its own world, one which is constructed as a transformation of non-artistic reality according to the law: 'if, then...' (Lotman 2009: 151). In commenting on Lotman's Culture and Explosion, Deltcheva and Vlasov (1996: 150151) write:

The very nature of the artistic world establishes the possibility to experience before its actual experiencing in non-artistic reality. The mental experiment precedes the historical experiment and is based on the formula "explosion plus gradual evolution." The very essence of explosion determines the unpredictability of the process, simultaneously ensuring its inexhaustibility and unfinalizability. The outcomes of historical experiment, on the other hand, can be predicted, since they are based on analytical data of non-experimental, factual information. Historical experiment rejects the notion of the accidental and establishes a unidirectional evolutionary channel oriented towards a finite goal. This scheme presents God as the Great Master who performs a chain of events known to him in advance...Art can be defined as the dichotomy of the text and the boundary of the text.

Lotman sees art as constantly struggling to overcome boundaries. His model replaces Hegel's linear evolution. The universe is an inexhaustible source of information and there is no finite goal (Deltcheva, Vlasov 1996: 151). In opposition to the linear model, Lotman introduces a third apex, which expands the area in which culture is oriented, "which compensates between the two existing entities, transforms it into a volumetric structure" (Deltcheva, Vlasov 1996: 157). The two models of evolution both have explosions that are obligatory, but in binary explosion the result is annihilation. Death is the only outcome (Deltcheva, Vlasov 1996: 151). Ternary explosion is a momentary eruption, characterized not by unidirectionality but by alternativity. In a ternary system, the result is defused. It neutralizes the destructive aspects of the explosion, amortizing and preserving the system from 
total destruction by accommodating the ideal to reality and guaranteeing the infinity of evolutionary processes.

In ternary social structures even the most powerful and deep explosions are not sufficient to encompass the entirety of the complex richness of social layers. The core structure can survive an explosion so powerful and catastrophic that its echo can be heard through all the levels of culture. (Lotman 2009: 166)

Here Lotman applies his concepts to the present world. The world mistrusts explosions (such as nuclear). If explosion is integrated into the ternary structure, it could be a positive, creative force. The ternary system of the West, Lotman predicts, is coming to be accepted by Russia rather than the binary, destructive system.

Lotman concludes with a hopeful optimism, namely that

The radical change in relations between Eastern and Western Europe, which is taking place before our very eyes may, perhaps, provide us with the opportunity to pass into a ternary, Pan-European system and to forego the ideal of destroying "the old world to its very foundations, and then" constructing a new one on its ruins. To overlook this possibility would be a historical catastrophe. (Lotman 2009: 174)

Lotman's hopeful comment, a wishful optimism leaves us with the respect for his wisdom but tinged with irony for today.

I conclude that acceptance of multiple realities does not mean that we must accept relativism as a final statement, and that we cannot continue to search for underlying universals. Moreover, we can accept and investigate concepts such as binarism and the heteroglossia of Bahtin. Lotman's semiosphere and beyond implies that space is so vast that we can continue to search for many realities. The universal human delight in art, music, and dance does not prove that these abilities are due to evolutionary survival of the fittest, for they have many functions and meanings. In this paper I have discussed why we need Bidney's insights and Lotman's open-ended vision of semiotics of culture, both of which embrace all forms of communication and reject borders that falsely enclose realities and limit thought and 
imagination. These scholars decry reductionism, oversimplification, and narrow-minded rejection of those questions too difficult to answer, all of which fail to lead us to new truths. They uphold instead the questioning minds that drive humans on in the search for all aspects of reality.

\section{References}

Baker, Lee 2004. Franz Boas out of the ivory tower. Anthropological Theory 4(1): 29-50.

Bahtin 1981 = Bakhtin, Michael 1981. The Dialogic Imagination, Four Essays. Austin: University of Texas Press. [Transl. Emerson, C. and Holquist, M.]

Bidney, David 1967 [1953]. Theoretical Anthropology. New York: Schocken Books. Boas, Franz 1911. The Mind of Primitive Man. New York: MacMillan.

- 1912. Change in Bodily Form of Descendants of Immigrants. London: Oxford University Press.

- 1927. Primitive Art. Cambridge: Harvard University Press

Bonnefoy, Yves. 1982. L'Arrière-pays. Paris: Gallimard.

Brumfiel, Elizabeth 2006. Cloth, Gender, and Continuity and Change. American Anthropologist 108(4): 862-877.

Bruner, Jerome 1990. Acts of Meaning. London: Harvard University Press.

Clifford, James.; Marcus, George. E. (eds.) 1986. Writing Culture. Berkeley and Los Angeles: University of California Press.

Crapanzano, Vincent. 1980. Tuhami: Portrait of a Moroccan Chicago. Chicago: University of Chicago Press.

- 1990. Afterward. In: Manganaro, Marcus (ed.), Modernist Anthropology. Princeton: Princeton University Press, 300-308.

- 1992a. Hermes' Dilemma and Hamlet's Desire: Essays on the Epistemology of Interpretation. Cambridge: Harvard University Press.

- 1992b. The postmodern crisis: Discourse, parody, memory. In: Marcus, G. (ed.), Rereading Cultural Anthropology. Durham: Duke University Press, 87103.

- 2004. Imaginative Horizons: An Essay in Literary Philosophical Anthropology. Chicago: University of Chicago Press.

- 2006. The scene. Anthropological Theory 6(4): 387-405.

D’Andrade, Roy 1995. The Development of Cognitive Anthropology. Cambridge: Cambridge University Press.

Deely, John 1990. Basics of Semiotics. Tartu: Tartu University Press. 
Deltcheva, Roumiana; Vlasov, Edward 1992. Lotman's Culture and Explosion: A shift in the paradigm of the semiotics of culture. Slavic and East European Journal 40(1): 148-152.

Emmeche, Claus. 1992. Modeling life: A note on the Semiotics of emergence and computation in artificial and natural systems. In: Sebeok, Umiker-Sebeok (eds.) 1992: 77-99.

Geertz, Clifford 1973a. Thick description: Toward an interpretive theory of culture. The Interpretation of Cultures. New York: Basic Books, 3-32.

- 1973b. Deep play: Notes on a Balinese cockfight. The Interpretation of Cultures. New York: Basic Books, 412-449.

- 1984. Distinguished lecture: Anti anti-relativism. American Anthropologist 86(2): 263-277.

- After the Fact: Two Countries, Four Decades, One Anthropologist. Cambridge: Harvard University Press.

Heyman, Josiah 2003. The inverse of power. Anthropology Theory 3(2): 139-156.

Hoffmeyer, Jesper 1999. The Vague Boundaries of Life. In: Taborsky (ed.) 1999: 151-169.

- 2008. Biosemiotics: An Examination into the Signs of Life and the Life of Signs. Chicago: University of Scranton Press, Chicago Distribution Center.

Ivanov, Vyatcheslav 1998. Izbrannye trudy po semiotike i istorii kul'tury, vol. 1. Moskva: Jazyki russkoj kul'tury.

Jakobson, Roman 1960. Closing statement: Linguistics and poetics. Style in Language. Cambridge: MIT Press, 350-377. [Sebeok, T. A. ed.]

Knauft, Bruce 2006. Anthropology in the middle. Anthropological Theory 6(4): 407-430.

Kull, Kalevi. 2000. Copy versus translate, meme versus sign: Development of biological textuality. European Journal for Semiotic Studies 12(1): 101-120.

- 2005a. Semiosphere and the dual ecology: Paradoxes of communication. Sign Systems Studies 33(1): 175-189.

- 2005b. Semiotics is a theory of life. Willamson, Rodney; Sbrocchi, Leonard G.; Deely, John. (eds.) Semiotics 2003. Ottawa: Legas, 15-30.

Kull, Kalevi; Salupere, Silvi; Torop, Peeter 1990. Semiotics has no beginning. In: Deely, John. Basics of Semiotics. Tartu: Tartu University Press), ix-xxv.

Kuhn, Thomas 1996 [1962]. The Structure of Scientific Revolutions. Chicago: University of Chicago Press.

Locke, John 1979[1824]. Essay Concerning Human Understanding. New York: Oxford University Press.

Lotman, Juri 1969. Lyudi i znaki. Sovetskaya Estoniya 1.02.

- 1970. The Structure of the Artistic Text. English translation 1977, Providence: Brown University Slavic Series.

- 1976. Semiotics of the Cinema. Ann Arbor: University of Michigan. 
- 1984. Kultuur ja organism. Tiivel, T.; Kull, K.; Neuman, T.; Sutrop, U. (eds.), Teooria ja mudelid eluteaduses. Eesti NSV Teaduste Akadeemia, 215-220.

- 1992. Universe of the Mind. Bloomington: Indiana University Press.

- 1996 [1990]. Vnutri myslyashchih mirov. Chelovek-tekst-semiosferaistoriya. Moskva: Yazyki russkoj kul'tury.

- 2009 [1992]. Culture and Explosion. Mouton. [Kul'tura i vzryv. Moscow: Gnozis.]

Lukes, Steven 2003. Power: A Radical View. London: Cambridge University Press.

Marcus, George E. 1992. A beginning. Cultural Anthropology 1(1): 3-5.

- 1993. Perilous States: Conversations on Culture, Politics, and Nation. Chicago and London: University of Chicago Press.

Maurer, Bill 2005. Introduction to 'Ethnographic Emergencies'. American Anthropologist 107(1): 1-4.

Ortner, Sherry 1984. Theory in anthropology since the sixties. Society for Comparative Study of Society and History 26(1): 126-166.

Pjatigorskij 1971[1962]. Some general remarks regarding the concept of text as multiform signal. In: Eimermacher, K. (ed.), Тексты советского литературоведческого структурализма. (München: Wilhelm Fink Verlag, 78-86.

Ponzio, Augusto; Petrilli, Susan 2001. Bioethics, semiotics of life and global communication. Sign Systems Studies 29(1): 263-275.

Portis-Winner, Irene 2006. Eric Wolf: A semiotic explanation of power. Sign Systems Studies 34(2): 334-354.

Portis-Winner, Irene; Winner, Thomas 1976. The semiotics of cultural texts. Semiotica 18(2): 101-156.

Rabinow, Paul 1986. Representations are social facts: Modernity and postmodernity in anthropology. In: Clifford, J.; Marcus, G.E. (eds.), Writing Culture. Berkeley and Los Angeles: University of California Press, 234-616.

Saussure, Ferdinand. 1966. Course in General Linguistics. New York: McGraw Hill. Searle, John R. 1995. The Construction of Social Reality. New York: The Free Press. Sebeok, Thomas A.; Umiker-Sebeok, Jean 1992. Biosemiotics. The Semiotic Web 1991. Berlin, New York: Mouton de Gruyter.

Sharman, Russell Leigh. 2006. Re/Making La Negrita: Culture as an aesthetic system in Costa Rica. American Anthropologist 108(4): 842-853.

Stocking, George W. 1974. The Shaping of American Anthropology 1885-1911. New York: Basic Books.

Taussig, Michael T. The Devil and Commodity Fetishism in South America. Chapel Hill: University of North Carolina Press.

Tedlock, Dennis; Manheim, Bruce 1993. The Dialogic Emergence of Culture. Chicago: University of Illinois Press.

Torop, Peeter. 1999. Cultural semiotics and culture. Sign Systems Studies 27: 9-23. 
- 2005. Semiosphere and/as the research object of culture. Sign Systems Studies 33(1): 159-170.

- New Tartu semiotics. S: European Journal for Semiotic Studies 2(1): 5-22.

Turner, Victor 1974. Dramas, Fields and Metaphors: Symbolic Action in Human Society. Ithaca: Cornell University Press.

- 1982. From ritual to theater. American Performing Arts Journal 89(5): 89-101.

- 1986. Dewey, Dilthey and drama: An essay in the anthropology of experience. Turner, V.; Bruner, E. M. (eds.), The Anthropology of Experience. Urbana: University of Illinois Press, 33-44.

Wolf, Eric 1964. Anthropology. Englewood Cliffs: Prentice-Hall.

- 1974. Introduction. Anthropology. New York: Norton. [2 ${ }^{\text {nd }}$ edition]

- 1999. Envisioning Power: Ideologies of Dominance and Crisis. Berkeley: University of California Press.

- 2001. Pathways of Power: Building the Anthropology of the Modern World. Berkeley: University of California Press.

Uexküll, Thure von; Wolfgang Wesiack 1997. Scientific theory: A bio-psychosocial model. In: Uexküll, Thure von. Psychosomatic Medicine. München: Urban and Schwarzenberg, 11-42.

Uspenskij B. A., Ivanov V. V., Toporov V. N., Pjatigorskij A. M., Lotman, J. M. 1973. Theses on the semiotic study of cultures (as applied to Slavic texts). In: Eng, Jan van der and Grygar, Mojmir (eds.), Structure of Texts and Semiotics of Culture. The Hague, Paris: Mouton, 1-28.

\section{Тропы прошлого и новые дороги в американской антропологии (или зачем антропологии нужна семиотика культуры)}

В статье описывается положение в американской антропологии, основоположником которой является Франц Боас, который работал во всех областях антропологии: в физической, культурной и социальной антропологии. Боас был храбрым полевым работником, который изучал жизнь эскимосов и вдохновил своих знаменитых учениц - Рут Бенедикт и Маргарет Мид - перейти существующие границы и заняться исследованиями нового типа. После этих выдающихся личностей американская антропология оказалась вновь во власти линеарного описательного позитивизма, поверхностных сравнений квантитативных черт культуры и ложных эволюционных схем, которые были неспособны познакомить нас с внутренними мирами и характером исследуемых народов. Что стало со значением, 
мечтами, поэзией, воображением, ценностями и самоопределениями? Исследование философа Дэвида Бидни 1953 года является в этом смысле откровением. Бидни озвучил и развеял все мои сомнения по части направлений в антропологии, и его работа является в каком-то смысле сводной моделью нарратива американской антропологии. Не читая работ Юрия Лотмана, Бидни в своих работах набросал идеи семиотики культуры Лотмана. В статье я пытаюсь описать по следам Бидни ложные представления в антропологии и показать, как эти ошибки частично преодолевались в некоторых более поздних антропологических исследованиях, которые занимались символизмом, работой художника и субъективными качествами исследуемых. Далее я пытаюсь дать обзор школы, основанной Лотманом, объект исследования которой охватывает человеческое поведение в его целостности, демонстрирует сложность значения и коммуникации на очень широком материале - от искусства и литературы до науки и философии, и отказывается от жесткого релятивизма и закрытых систем. Школа Лотмана вдохновляет всех, кто хочет, чтобы антропология охватывала как себя, так и Другое и бахтинское двойное значение. Бидни вдохновил данную статью, как призыв изучить все возможные миры, - не отказаться от науки и реальности, а изучить глубинные связи и важнейшую роль эстетического фактора в дебрях коммуникации.

\section{Silmitsi eriolukordadega: minevikurajad ja uued suunad ameerika antropoloogias (ehk miks ameerika antropoloogial on vaja kultuurisemiootikat)}

Käesolev artikkel räägib sellest, mis on saanud ameerika antropoloogiast, millele pani aluse Franz Boas, kes tegeles kõigi antropoloogia liikidega: füüsilise, bioloogilise ja kultuurantropoloogiaga. Boas oli vapper välitööline, kes uuris eskimote alasid ning inspireeris oma kahte kuulsat ópilast - Ruth Benedicti ja Margaret Meadi - uut sorti uuringutes üle kehtivate piiride astuma. Peale neid säravaid kujusid vajuti taas lineaarse kirjeldava positivismi, kvantitatiivsete kultuurijoonte pealiskaudsete võrdluste ja väärate evolutsiooniliste skeemide rüppe, mis ei tutvustanud meile ei uurimisaluste rahvaste sisemisi maailmu ega iseloomu. Mis sai tähen- 
dusest, unistustest, luulest, kujutlusvõimest, väärtustest ja enesemääratlustest? Filosoof David Bidney 1953. aasta uurimus oli selles mõttes ilmutuslik. Bidney sõnastas ja hajutas kõik mu kahtlused antropoloogia suundade osas ning tema töö toimib teatud mõttes ameerika antropoloogia narratiivi koondmudelina. Bidney visandas päris mitmes aspektis Lotmani kultuurisemiootika ideid, olemata Lotmani töid loomulikult lugenud. Käesolevas artiklis üritan kirjeldada eksiarvamusi antropoloogias, mille Bidney defineeris, ning näidata, kuidas neist eksiarvamustest on osaliselt jagu saadud mõnedes hilisemates antropoloogilistes uurimustes, mis keskendusid sümbolismile, kunstnikutööle ja uurimisaluste inimeste subjektiivsetele omadustele. Seejärel üritan anda, nii hästi kui võimalik, ülevaadet Lotmani koolkonnast, mille uurimisobjekt hõlmab kogu inimkäitumist, demonstreerib tähenduse ja kommunikatsiooni keerukust väga laialdase materjali peal kunstist ja kirjandusest teaduse ning filosoofiani välja, ning mis ütles lahti rangest relativismist ja suletud süsteemidest. Lotmani koolkond on inspiratsiooniks kõigile neile, kes tahavad, et antropoloogia hõlmaks nii ennast kui Teist ja ka Bahtini topelttähendust. Bidney oli käesoleva artikli inspiratsiooniks kui üleskutse uurimaks laiemalt kõiki võimalikke maailmu - mitte hülgama teadust ja reaalsust, vaid uurima sügavamaid sisemisi seoseid ning esteetilise faktori ülimalt tähtsat rolli kommunikatsiooni keerdkäikudes. 